\title{
APROPRIAÇÃO E INDETERMINAÇÃO NA POESIA DE RUI PIRES CABRAL: DA MEMÓRIA PESSOAL À INSPIRAÇÃO "MAIS MATERIAL POSSÍVEL"
}

\author{
Tamy de Macedo Pimenta
}

\begin{abstract}
RESUMO
Este artigo apresenta uma reflexão sobre técnicas de apropriação utilizadas na obra do poeta português contemporâneo Rui Pires Cabral. O autor insere, desde seus primeiros títulos, trechos de músicas ou de livros em seus poemas, dialogando, portanto, com outras artes por meio da escrita. Esse diálogo se torna ainda mais claro com o recente uso da colagem pelo poeta, constituindo-se na inspiração "mais material possível".
\end{abstract}

PALAVRAS-CHAVE: Poesia contemporânea; apropriação; colagem.

Houve pioneiros para tudo, a minha própria solidão foi hasteada noutros livros.

(CABRAL, 2003, p. 49)

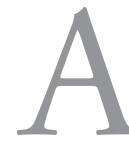

apropriação da palavra do outro, por meio de técnicas, como a citação e a colagem, é um aspecto notável da poesia modernista e o domínio da noção de originalidade, sendo esta entendida como "sinônimo de novidade, invenção, criatividade e independência da mente" (PERLOFF, 2013, p. 55), o modernismo recuperou o que antes fora amplamente usual, sobretudo na época clássica ${ }^{1}$. Dessa maneira, publicaçôes como os Cantos de

1 "O filósofo Chrysippus ajuntava a seus livros não apenas passagens, mas obras inteiras de outros autores e em um deles a Medeia, de Eurípides; e Apolodoro dizia que quem subtraísse 
Erza Pound e The Waste Land de T. S. Eliot - compostas por várias citaçóes e alusôes, inclusive em outras línguas -, mobilizaram a poética e crítica do século $\mathrm{XX}$, tornando possível a expansão de técnicas semelhantes na poesia mais recente, na contemporaneidade. Dissertando sobre este tema, a crítica americana Marjorie Perloff afirma que:

No clima do novo século [...] parecemos estar testemunhando uma reviravolta poética do modelo de resistência da década de 1980 para o diálogo - um diálogo com textos anteriores ou outras mídias, com a técnica do "escrever-através" ou écfrases que permitam ao poeta participar de um discurso maior e mais público. A inventio está cedendo espaço para a apropriaçáo, a restrição elaborada, a composição visual e sonora e a dependência da intertextualidade. (PERLOFF, 2013, p. 40-41)

Embora Perloff se tenha baseado principalmente no cenário americano², creio ser possível utilizar as descriçóes citadas para pensar a poesia ocidental contemporânea, já que as observaçóes levantadas pela autora se relacionam com um fenômeno global da literatura. Por este motivo, percebo tal diálogo com outros textos e outras mídias na produção portuguesa mais recente, especialmente nos poetas cujas obras datam dos anos 90 em diante $^{3}$. Deter-me-ei, porém, na poética de Rui Pires $\mathrm{Cabral}^{4}$, analisando a utilização das técnicas de citação e colagem em seus livros.

o que houvesse ali de estrangeiro, o seu papel ficaria em branco.” (MONTAIGNE, 1962, 26 apud COMPAGNON, 2007, p. 140).

2 A própria autora escreve no prefácio que " $O$ gênio não original [...] é um livro bastante americano" (PERLOFF, 2013, p. 14).

3 Aqui, penso sobretudo nos poetas reunidos em torno da antologia Poetas sem qualidades, publicada nos anos 2000 pela editora Averno em Lisboa.

4 Poeta e tradutor formado em História pela Universidade do Porto, nascido em Macedo de Cavaleiros, Portugal, no ano de 1967. Seu primeiro livro, Qualquer Coisa Estranha, de contos, foi publicado em 1985 e a ele se seguiram mais catorze, de poesia: Pensáo Bellinzona e Outros Poemas (1994), Geografia das estaçôes (1994), A super-realidade (1995), Música antológica \& onze cidades (1997), Praças e quintais (2003), Longe da aldeia (2005), Capitais da solidão (2006), Oráculos de cabeceira (2009), A Pocket Guide to Birds (2009), Biblioteca dos Rapazes (2012), Broken (2013), Stardust (2013), Álbum (2013) e OH! LUSITÂNIA (2014). Seus poemas estão presentes em antologias, cujas principais são Anos 90 e agora: uma antologia da nova poesia portuguesa (2001), Poetas sem qualidades (2002), 9 poetas para o século XXI (2003) e o segundo volume de Portugal, O (2007). Como tradutor de língua inglesa, destacam-se os trabalhos com os livros Uma Casa no Fim do Mundo, Sangue do Meu Sangue e Dias Exemplares, de Michael Cunningham. 


\title{
APROPRIAÇÕES MUSICAIS
}

O autor afirmou considerar Geografia das estaçóes como seu primeiro título, já que, segundo ele, Pensão Bellinzona e Outros Poemas consistia em uma plaquete, cuja maioria de poemas veio a integrar Geografia 5 . Neste primeiro título, então, pode-se notar a presença de elementos diversos na escrita pirescabralina, elementos estes que estabelecem ligaçóes com objetos exteriores ao livro. Isso pode ser observado, por exemplo, no poema "SING ME TO SLEEP":

\author{
SING ME TO SLEEP \\ para a Marjan, onde quer que esteja \\ O tojo abundava nas vertentes, \\ havia as rochas, os montes \\ amarelos, o rumor fundo dos bichos \\ na arcadura das chãs.
}

Entre o meu silêncio e o teu

cresceu um verso com a tua boca

perto dos meus sentidos.

Sabíamos que a chuva acabaria

por voltar. As tuas cartas

ainda as tenho.

(CABRAL, In: MAFFEI, 2007, p. 35)

O título do poema, em itálico, indica duplamente a condição estrangeira da língua empregada - inglês, diferentemente do português presente na dedicatória e nos versos seguintes - e do texto inserido. Embora não haja notas de fim ou de rodapé que indiquem a origem da frase, uma rápida pesquisa eletrônica nos indica a canção "Asleep" ("Adormecido", em português) da banda de rock britânica The Smiths. Como músicas dessa mesma banda também aparecem em outros livros de Rui Pires Cabral, acreditamos ser possível pensar "Asleep" como fonte da frase colocada como título do poema supracitado. Assim,

5 Tais afirmações foram feitas a mim pelo poeta em conversa informal. 
a melodia pausada dialoga com o ritmo também pausado dos versos, por meio de um uso extenso de nasais e sibilantes ("abundava", "vertentes", "montes", "fundo", "chãs", "silêncio", "sentidos", "tenho") que também está presente no título "SING ME TO SLEEP", com o emprego do fonema/s/ em "sleep" e "sing" e, nesta última palavra, do /ñ/. De maneira semelhante, é possível relacionar a letra melancólica da canção ${ }^{6}$ com o tom nostálgico do poema, que contrasta o encontro amoroso das duas primeiras estrofes com a certeza da despedida - "Sabíamos que a chuva acabaria por voltar" - e com a concretude dos resquícios que marcam o fim - "As tuas cartas/ ainda as tenho". Se em "Asleep" o sono e a morte são o fim cantado, no poema é a finitude do amor e a permanência da memória que são escritas. A dedicatória, logo abaixo do título, é, assim como este último, uma busca por interlocução, por contato. O imperativo "SING ME TO SLEEP" não indica seu interlocutor, enquanto a dedicatória, embora especifique "Marjan", indetermina seu paradeiro. Desse modo, a apropriação de um outro texto - e de outra mídia, na medida em que a canção é tanto poema como melodia - permite associaçôes e interpretações variadas, sendo o mencionado acima somente uma possibilidade de pensá-las. Tal relação com canções é explorada amplamente no terceiro livro de Rui Pires Cabral, Música Antológica \& Onze Cidades, publicado em 1997. Como o próprio título demonstra, o livro é dividido em duas partes: "Música Antológica”, composta por 27 poemas; e "Onze Cidades", composta por 11. Interessa-nos neste momento analisar a primeira delas, já que os títulos de

6 Sing me to sleep/Sing me to sleep/I'm tired and I/I want to go to bed/Sing me to sleep/Sing me to sleep/ And then leave me alone/ Don't try to wake me in the morning/ 'Cause I will be gonel Don't feel bad for mel I want you to know/ Deep in the cell of my heartl I will feel so glad to go/ Sing me to sleep/Sing me to sleep/I don't want to wake up/ On my own anymore/ Sing to me/ Sing to mel I don't want to wake up/ On my own anymorel Don't feel bad for mel I want you to knowl Deep in the cell of my heart/ I really want to go/ There is another world/ There is a better world/ Well, there must bel Well, there must bel Bye bye. Tradução: Cante pra eu dormir/ Cante pra eu dormir/ Eu estou cansado e eu/ Eu quero ir pra cama/ Cante pra eu dormir/ Cante pra eu dormir/ E então me deixe sozinho/ Não tente me acordar de manhã/ Pois eu terei ido/ Não se sinta mal por mim/ Eu quero que você saiba/ No fundo da cela de meu coração/ Eu ficarei feliz de ir/ Cante pra eu dormir/ Cante pra eu dormir/ Eu não quero mais acordar sozinho/ Cante pra mim/ Cante pra mim/ Eu não quero mais acordar/ Não se sinta mal por mim/ Eu quero que você saiba/ No fundo da cela de meu coraçáo/ Eu ficarei feliz de ir/ Há um outro mundo/ Há um mundo melhor/ Bem, deve haver/ Bem, deve haver/ Adeus. (http://www. vagalume.com.br/the-smiths/asleep-traducao.html\#ixzz37du4sQsT/, consultado em julho de 2014) 
seus poemas são retirados de cançóes, assim como ocorreu no poema anteriormente citado. Novamente, não há indicaçóes por notas que nos permitam ter acesso às fontes e, então, foi-nos necessário recorrer à pesquisa para tentar traçar diálogos entre as duas manifestações artísticas ${ }^{7}$. Em resenha sobre este livro, o poeta e crítico português Joaquim Manuel Magalhães comenta sobre a diferença entre suas duas divisóes:

Se "Onze Cidades" torna muito claro o local geral (ainda que não um paisagismo demasiado concreto) onde o devir das palavras se processa, "Música Antológica" não pretende estabelecer com idêntica nitidez quais as obras, quais os autores que no título são invocados. Deste modo, distancia-se de qualquer espécie de variação directa sobre a obra musical no tecido vocabular subsequente. Trata-se de uma música de tela na memória, que pode ter ou não ter a ver com o declarado nos poemas. É essa indefinição que é o sentido do seu uso. (MAGALHĀES, 1999, p. 271)

Segundo Magalhães, então, a indefinição das músicas e de seus autores não permite relaçôes diretas entre canção e poema, sendo esta indefinição o próprio sentido de seu uso. Ainda nas palavras do poeta-crítico:

Mesmo quando saibamos reconhecer qual a obra referida, uma ou outra é fácil que provoque esse reconhecimento, o processo poético obriga a entendê-lo como pouco relevante a não ser para este intuito: o poema náo é dependente do título, o título é dependente da memória pessoal que não depende de qualquer <<verdade>> para ter a ver com as declaraçóes textuais. (MAGALHÂES, 1999, p. 271)

De fato, se em alguns poemas é possível traçar paralelos com a música do título, em outros pouco se pode achar além de um fundo musical para os versos ali encontrados, "uma 'banda sonora' para a dança do tempo pessoal” (MAGALHÃES, 1999, p. 271). No último poema da

7 A pesquisa foi feita por meio eletrônico e levou em consideração principalmente as datas das cançóes encontradas, já que o livro foi publicado em 1997. 
série "Música Antológica", por exemplo, há alguns pontos de contato entre canção e poema que podem ser observados:

\author{
MY FUNNY VALENTINE \\ tu estás do meu lado \\ a noite inteira, anjo de máos pequenas \\ nos despenhadeiros da terra
}

esta estrada não nos levará muito longe

mas sim eu serei o teu amigo

até ao fim.

(CABRAL, 1997, p. 35)

A música "My funny valentine", de Frank Sinatra, possui uma melodia jovial e letra alegre ${ }^{8}$, que contrastam com o tom dos versos referidos Se o interlocutor da cançâo é - como o próprio título evidencia - engraçado, doce e com caras “infotografáveis", o "tu” do poema é menos descrito e, por tal razão, mais misterioso. Uma figura nebulosa, um anjo cujas "mãos pequenas" são as únicas características cantadas. E é justamente esse detalhe que nos permite ligá-lo à canção, já que a pequenez também é aparente na "namoradinha” da música de Sinatra, que pergunta "Sua figura é menos que grega?/ Sua boca está um pouco fraca?" (grifos meus). Esse grau diminutivo que acompanha as mãos do "tu" no poema também pode ser observado no emprego exclusivo de minúsculas ao longo do poema, assim como na estrada que "não nos levará muito longe" - estrada de curta distância, portanto - que, por sua vez, se contrapóe à longa "noite inteira" em que "tu estás do meu lado". Assim, a plenitude da noite, na primeira estrofe, despenca na curta estrada do envolvimento que, porém, manterá a amizade. Essa polaridade entre longo e curto é graficamente repre-

8 My Funny Valentinel Sweet comic valentinel You make me smile with my heart/ Your looks are laughablel unphotographablel yet your my favorite work of artl Is your Figure less than Greek?I Is your mouth a little week?/ When you open it to speak/ Are you smart? But don't change your hair for mel Not if you care for me/ Stay little valentine stay/ Each day is Valentines day. Tradução: "Minha namorada engraçadal doce, cômica namoradal Você me faz sorrir com o meu coração/ Suas caras são cômicas, / infotografáveis/ e você é a minha obra de arte favorital Sua figura é menos que grega?/ Sua boca está um pouco fraca?l Quando você a abre para falarl é inteligente?l Mas não mude o cabelo por mim/ Não se você se importar comigo/ Fique, namoradinha, Fiquel Todo dia é dia dos namorados" 
sentada no poema, que intercala versos longos e curtos. Desse modo, é possível encontrar semelhanças entre a canção e o poema "My funny valentine" sob o signo do diminutivo, da pequenez, muito embora este seja explorado de maneiras bastante distintas em cada uma das obras.

Em contrapartida, é interessante notar que a canção pode fazer-se presente nos poemas por outros meios. Em "Kathleen", por exemplo, ela é aludida no meio dos versos, como se fosse chamada a participar do cenário composto pela escrita de Rui Pires Cabral, sendo mais do que um título ao tornar-se elemento constitutivo do corpo do poema:

O amor nos seus aposentos

sem luz, os quadros inacabados, a cama húmida

e por fazer. Fui eu que escolhi a canção: um assalto ao pano friável da consciência.

(CABRAL, 1997, p. 13)

Dessa maneira, esta estrofe demonstra a indefinição exposta por Joaquim Manuel Magalhães, na medida em que ela levanta ainda mais questóes a respeito das relaçóes entre música e poema: Seria a canção escolhida no poema a mesma canção de seu título? Quais seriam as consequências da inserção de "Kathleen" também no meio dos versos? Seria a canção escolhida uma música ficcional ou justamente a do título? De fato, a única afirmação que se pode fazer diante desses questionamentos é que, como escreveu Magalhães, é a própria emergência dessas questôes - a indeterminação - o sentido do uso da canção, aqui tanto no título como no corpo do poema.

Portanto, em seus primeiros livros o poeta apropriou-se principalmente de músicas, utilizando seus títulos ou partes de suas letras como títulos de poemas. Estabelece-se, dessa forma, um diálogo com outra mídia ao mesmo tempo em que se cita a parte escrita - a letra - dessa outra obra artística, criando-se múltiplas possibilidades de leitura.

\section{Apropriações de livros 'abertos ao acaso'}

Em 2009 - 12 anos após a publicação de Música Antológica \& Onze Cidades -, Rui Pires Cabral adotou um procedimento semelhante ao an- 
terior, mas agora com a própria literatura. Oráculos de Cabeceira encena a elaboraçấo de um livro cujos poemas sáo compostos a partir de exemplares "abertos ao acaso" (CABRAL, 2009, p.49). A ideia de acaso, de aleatoriedade dos acontecimentos, de desconcerto do mundo - para pensarmos em termos camonianos - percorre o livro que, ao final, enumera os volumes que estiveram à cabeceira deste poeta fingidor ${ }^{9}$ (figura seguinte).

\section{ABERTOS AO ACASO}

1 Frugres Karuntrur, A Joturney Round My Skull [tradução inglesa de Vernon Duckworth Barker], Corvina, Budapeste, 1992, p. 52.

${ }^{2}$ A. J. A. Srmons, The Quest for Corvo, The New York Review of Books, Nova lorque, 2001 , p. 87.

${ }^{3}$ Irts Murdoch, O Mar, o Mar [tradução de José Miguel Silva], Relógio D'Água, Lisboa, 2005 , p. 212.

4 Agustiva Bessa-Luis, Comversaçōes com Dmitri e Outras Fantasias, Na Regra do Jogo, Lisboa, 1981, p. 11.

5 BruNo Schu17, Tratado dos Manequins on O Segundo Génesis [tradução de Aníbal Fernandes], \&cetc, Lisboa, 1983, p. 17.

6 Eveirn WaUgh, A Little Learning. Sidgwick \& Jackson, Londres, 1973 , p. 189.

7 James Gavin, Deep in a Dream: The Long Night of Chet Baker, Vintage, Londres, 2003, p. 329.

8 Charles Dickens, The Christmas Books, Cassell \& Company, Londres, Nova lorque, Toronto c Melbourne, 1910, p. 136.

9 Cresare PAvese, A lua e as Fogueiras [tradução de Manuel de Seabra], Arcádia, Lisboa, s/d, p. 126.

10 Derfo Jarman, Modem Nature, Vintage, Londres, 1992, p. 138.

11 WrLlam BECKFord, Diário de William Beckford em Portugal e Espanha [tradução de João Gaspar Simões], Biblioteca Nacional, Lisboa, 1988, p. 123.

12 Jodo Miguil Fernandes Jorge, lim Quatro Cheio de Espelhos, Quetzal, Lisboa, 1987, p. 61.

13 Henry James, The Europeans, Penguin, Harmondsworth, 1985, p. 54 .

14 Alaert Camus, A Morte Feliz [traduçäo de José Carlos González], Livros do Brasil, Lisboa, s/d, p. 102.

15 CHRISTOPHER ISHERwOOD, Lions and Shadows, Minerva, Londres, 1996, p. 148.

9 Remeto aqui ao poema "Autopsicografia" de Fernando Pessoa para enfatizar a estratégia de ficcionalização empregada por Rui Pires Cabral, uma vez que, assim como ocorrera com os títulos de "Música Antológica", há aqui uma indeterminação no que diz respeito à legitimidade do acaso que fez o escritor abrir seus livros de cabeceira para compor seus versos. 
São romances, livros de poesia, narrativas de viagem e, até mesmo, cartas, de diversos autores e países, mas sobretudo de origem portuguesa ou anglófona, cujas frases serviram de título e, mais que isso, de mote para a escritura dos poemas. Tal forma de composição faz-nos recordar os incipit do escritor francês Louis Aragon, que, em seu ensaio Je n'ai jamais appris à écrire ou Les Incipit, publicado em 1969, afirmou escrever seus livros - no caso, os romances - a partir de uma única frase, o incipit. Em comunicação sobre este tema, Corinne Grenouillet diz:

O famoso mito que Aragon constitui para seus próprios fins é o de uma escrita que seria primeiramente uma leitura: o autor começaria a escrever sob o impulso de uma frase lida, ouvida, ou de uma frase que despertasse sua atenção, que constituiria a matriz de seu livro. Diante de todas as frases produzidas por este mecanismo de criação, ele seria como um leitor descobrindo um texto do qual estaria ausente toda premeditação, toda direção voluntariamente iniciada. ${ }^{10}$ (GRENOUILLET, 1998, s/p.)

Desse modo, o incipit seria uma frase a partir da qual toda a constituição do livro seria feita. Logo, nessa experiência, o autor é, antes de tudo, leitor, inclusive de seus próprios livros:

Diante de meus romances, a partir da primeira frase, do gesto permutador do qual ela surge como que por acaso, eu sempre estive no estado de inocência de um leitor [...] Compreendamme bem, não é maneira de dizer, metáfora ou comparação, eu jamais escrevi meus romances, eu os li. ${ }^{11}$ (ARAGON, 1969 apud GRENOUILLET, 1998, s/p.)

10 Minha tradução. No original: Le mythe fameux qu'Aragon constitue à ses propres fins est celui d'une écriture qui serait d'abord une lecture: l'auteur se mettrait à écrire sous la poussée d'une phrase lue, entendue, ou d'une phrase de réveil qui constituerait la matrice de son livre. Face à toutes les phrases ensuite engendrées par ce mécanisme de création, il serait comme un lecteur découvrant un texte d'où serait absente toute préméditation, toute direction volontairement initiée.

11 Minha tradução. No original: Mes romans, à partir de la première phrase, du geste d'échangeur qu'elle a comme par hasard, j'ai toujours été devant eux dans l'état d'innocence d'un lecteur [...]. Comprenez-moi bien, ce n'est pas manière de dire, métaphore ou comparaison, je n'ai jamais écrit mes romans, je les ai lus. 
Para o autor, então, a apropriação de frases de outrem desencadeia um processo de criação complexo, como se o texto surgisse como unidade independente do sujeito escritor, desde seu princípio. Cabe ao escritor somente a leitura: tanto a da frase matriz como a do próprio texto a partir dela surgido.

Não nos interessa, no presente momento, questionar as afirmações de Aragon, mas sim comparar seu mecanismo de composição com o adotado por Rui Pires Cabral em Oráculos de Cabeceira. As frases "abertas ao acaso" (CABRAL, 2009, p. 49) deste assemelham-se aos incipit do francês, já que são elas que desencadeiam os poemas do livro, assim como as frases de Aragon funcionam como matrizes para seus romances. Há, nos dois casos, a afirmação do acaso como agente da escolha das frases e, consequentemente, da criação dos textos. Dessa maneira, ocorre um apagamento do sujeito escritor, do poeta, em detrimento do acaso e da citação, às quais são creditadas a composição.

Semelhantemente, nos poemas, ocorre uma indeterminação, na medida em que se fundem o universo do livro citado com a materialidade dos versos ali presentes. Isto pode ser observado em "Não quero saber de ti":

Faz meses que não escreves e aquele postal em branco que chegou da tua terra não tinha remetente

nem resposta, só a imagem no verso: um verão genérico com muitas flores de estufa e um fundo imaculado

de varandas e relvados.

Não queres saber de mim, mas eu posso confessar-te que passei todo o inverno

entre as tropas de Massena, na fronteira, no Buçaco e enquanto eles avançavam reino adentro, de capítulo 
em capítulo, para ganhar ou perder outra batalha, eu ficava cada vez mais para trás, nas colinas, com os mortos,

nos plainos abandonados, entre rascunhos de versos à paisagem em destroços. Olha a grande novidade. (CABRAL, 2009, p. 26)

A citação-título remete, de acordo com as notas de fim inseridas por Pires Cabral, ao Diário de William Beckford em Portugal e Espanha, livro fixado a partir de manuscritos adormecidos durante mais de um século, que reproduz as impressóes do viajante William Beckford (aristocrata inglês) durante sua passagem pela Península Ibérica, entre 1787 e 1788. Um livro de viagem, portanto, inserido num livro de viagens intertextuais pela literatura. Após o título, as três primeiras estrofes do poema parecem indicar o tom corriqueiro e melancólico encontrado ao longo da obra de Rui Pires Cabral; porém, a quarta estrofe introduz termos estranhos - tais como o título - a esta atmosfera ("Massena”, "Buçaco", "reino", "capítulo") que continuam na quinta ("capítulo", "batalha”, "colinas") e até na sexta e última estrofe, na qual a escrita - no início do poema presente pela menção a um "postal em branco" - é retomada pelos "rascunhos de versos" e associada "à paisagem em destroços". Assim, ocorre aqui uma justaposição de cenários e tons, que se combinam de maneira a indeterminar a paisagem do poema, assim como sua autoria, uma vez que se mesclam as escritas de Cabral e de Beckford. Há também, para além da indeterminação, um tom cáustico que anula e destrói simultaneamente o discurso do início do poema e o do Diário, já que a figura do soldado que fica "cada vez mais para trás" se transforma - lentamente, por meio de vivências semelhantes "nas colinas, com os mortos, /nos plainos abandonados" - na figura de poeta. Poeta, todavia, baudelairiano, não aurático, que escreve versos aos destroços vistos e que ironiza sua própria condição: "Olha a grande novidade.” Assim, a indeterminação neste caso ocorre juntamente de um deslocamento corrosivo, que sobrepóe e mobiliza tanta o escrito citado como o do próprio poema. 
Tais reflexôes nos trazem novamente as palavras de Joaquim Manuel Magalhães sobre ser essa indeterminação a própria razão de seu uso. Desse modo, embora se mude o material com o qual se faz diálogo - a literatura, em vez da música -, permanecem as técnicas da citação e suas recorrentes indeterminaçôes.

\section{Citação, recorte e colagem}

A citação, como vimos, é um recurso recorrente na poesia desde o século XX e, principalmente, nas produçóes mais recentes - como a de Rui Pires Cabral. Em estudo sobre esta técnica, Antoine Compagnon (2013, p.11-12) a relaciona com a primeira prática do papel, ligada à infância, do recortar e colar:

Recorte e colagem são as experiências fundamentais com o papel, das quais a leitura e a escrita não são senão formas derivadas, transitórias, efêmeras [...] É por isso que se deve conservar a lembrança dessa prática original do papel, anterior à linguagem, mas que o acesso à linguagem não suprime de todo, para seguir seu traço sempre presente, na leitura, na escrita, no texto, cuja definição menos restritiva (a que eu adoto) seria: $o$ texto é a prática do papel. E no texto, como prática complexa do papel, a citação realiza, de maneira privilegiada, uma sobrevivência que satisfaz à minha paixão pelo gesto arcaico do recortar-colar.

Isto posto, podemos atribuir ao uso da citação, inclusive pelo poeta aqui estudado, a mescla da experiência infantil do papel (recorte e colagem) com sua prática complexa (texto). Ao apropriar-se de cançóes e frases de outros autores, Pires Cabral recorta os trechos que escolhe - descontextualizando-os de sua origem - e cola-os - recontextualizando-os -, inserindo-os em um novo e outro texto. Tal incorporação de elementos externos anteriormente ocorreu nas artes plásticas, como nos lembra Perloff (2013, p. 56):

A apropriação, a citação, a cópia, a reprodução - essas coisas há décadas são centrais às artes visuais: pensa-se em Duchamp, cuja obra inteira consiste de "cópias" e materiais achados; em Christian Boltanski, cujas "obras de arte" eram fotografias 
de seus colegas de classe reais durante a idade escolar; ou nas autoimagens cuidadosamente preparadas de Cindy Sherman.

De fato, se pensarmos na collage ${ }^{12}$, é possível relacioná-la com o mecanismo da citação, já que ambos têm na apropriação seu fundamento. Se na collage juntam-se à tela elementos materiais, como pedaços de tecido ou de madeira, na citação juntam-se às palavras de quem escreve outras palavras anteriormente publicadas. Rui Pires Cabral, a partir de 2012, passou a compor livros que adotam a collage juntamente com a citação, utilizando-se de dois mecanismos que, como vimos, são semelhantes.

Assim, em 2012, o poeta publica Biblioteca dos Rapazes, livro formado por recortes de figuras e ilustraçóes diversas, assim como por recortes de frases ou palavras. A citação, antes indicada em seus livros pelo itálico ou pelas aspas, agora é indicada de maneira mais material e visível, já que as frases são recortadas de sua fonte, reproduzidas e então coladas nas páginas. Em nota, Pires Cabral relata que as imagens do livro provêm de "revistas e postais antigos, fotografias de anônimos, velhas enciclopédias juvenis, calendários, monografias fotográficas de cidades estrangeiras, além das estampas e ilustrações dos livros" (CABRAL, 2012, p. 5), enquanto as obras literárias recortadas são listadas ao final, assim como ocorrera com Oráculos de Cabeceira. Segundo o próprio autor, os livros listados ao final inspiraram a escritura dos poemas, sendo essa inspiração "no sentido mais material possível" (CABRAL, 2012, p. 5). Estes livros são romances de aventura ou de literatura juvenil, sendo grande parte de autoria de Júlio Verne. Dessa forma, esses materiais são trabalhados e dispostos de modo a criarem o que pode ser chamado de poema-colagem, como o seguinte:

12 Técnica utilizada principalmente por artistas cubistas, futuristas e surrealistas e que insere diferentes texturas e objetos em telas. Segundo Greensberg $(1958$, s/p.) ainda não se decidiu quem inventou a collage, Braque ou Picasso, já que ambos afirmaram ser o inventor dessa técnica. 

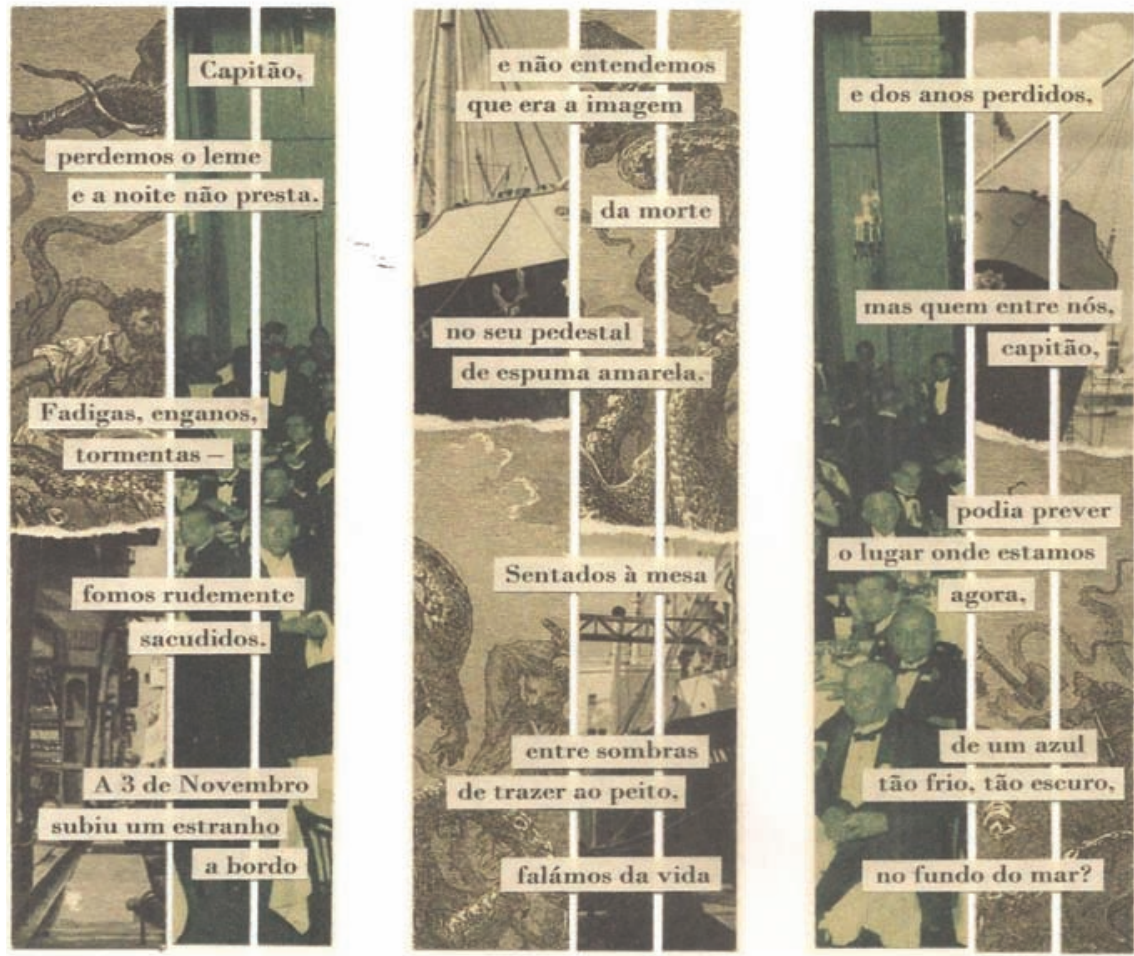

(Figura 2: CABRAL, 2012, p. 31)

Percebe-se, então, que embora haja uma série de recortes na página, pedaços de uma mesma imagem se repetem e se complementam de maneira desordenada. Também é possível ver uma forma que acompanha todos os poemas-colagem do livro, que são sempre divididos em três colunas que, por sua vez, são transpassadas por linhas brancas que as dividem em três partes. No poema supracitado, essas imagens relacionam-se entre si, traçando um quadro de aventura e fantasia, com monstros marítimos, navios e homens. Esse contexto, notavelmente, pertence à maioria das obras recortadas para a feitura de Biblioteca, como observei anteriormente em resenha ao livro:

Essas figuras são comuns nos livros juvenis que serviram como matéria verbal e imagética para o livro de Rui Pires Cabral (e é interessante ressaltar que 16 dos 36 títulos utilizados são 
da autoria de Júlio Verne), assim como o tema da morte. Em histórias de aventura, o perigo é o principal artifício para manter a tensão do enredo, e o fantasma da morte sempre assombra os personagens (PIMENTA, 2013, p. 278).

Assim, os títulos citados tornam-se inspiração material, mas também temática. Parte-se dos romances de aventura para, com seus símbolos e imagens, tecer novos poemas que, portanto, com eles se relacionam.

Esse diálogo com as obras recortadas, assim como a forma repartida das colagens, também está presente em Broken, livro seguinte do autor, publicado em 2013. Neste, porém, os poemas-colagem são inspirados em um único título. Em nota ao livro, nos diz o poeta:

O presente ciclo de poemas foi desenvolvido a partir de algumas palavras extraídas de Unbroken - O Submarino Fantasma da Guerra de 1939-45, um relato autobiográfico Alastair Mars publicado em 1957 pela Imprensa Nacional de Publicidade. Assim se quebrou, digamos, a história do HMS Unbroken. (CABRAL, 2013, s/p.)

Ao quebrar, recortar, a história do submarino "Unbroken” (inquebrável), o poeta transforma-o em "Broken" (quebrado). As tesouras de Pires Cabral quebram o que, no domínio da ficção, se diz "inquebrável”, transformando esses recortes quebrados em um novo livro. Diferentemente do ocorrido na obra anterior, nesta o autor não explica a origem das imagens usadas para fazer as colagens. Podemos observar fotos e ilustraçóes em preto e branco, mas não nos é dada a fonte destas: 


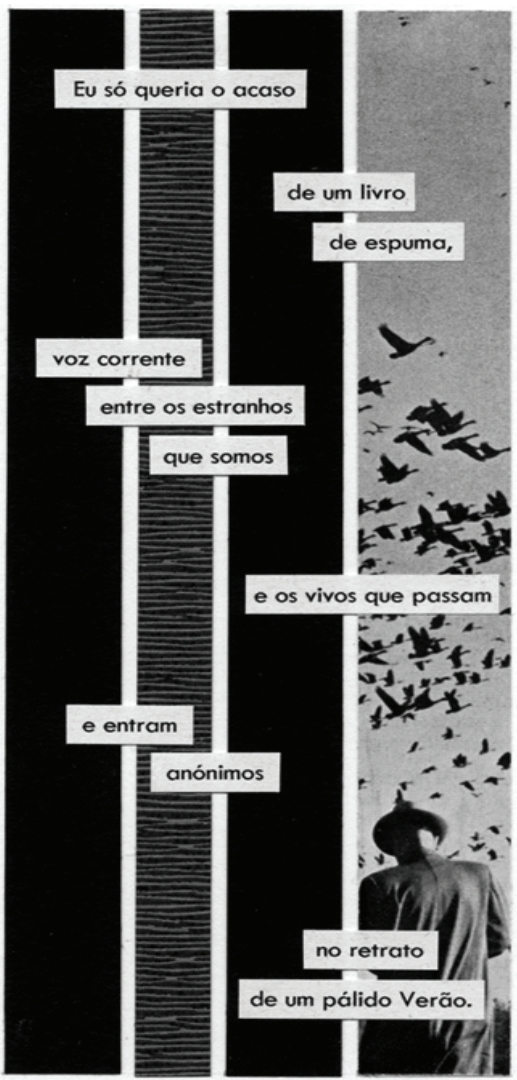

(Figura 3: CABRAL, 2013, s/p)

Como já observado, o poema é repartido por linhas brancas, porém, aqui não há colunas, e são três linhas, dividindo quatro partes. As três primeiras são mais lisas, enquanto a última é formada inteiramente por uma foto. A primeira e a terceira parecem complementar-se, já que possuem a mesma cor. A foto, por sua vez, embora destoe das outras imagens da colagem, tem os mesmos tons cinzas e pretos das partes ao seu lado. As linhas brancas parecem querer organizar a colagem, enquanto as palavras, em contrapartida, continuam desordenadas. Neste poema, assim como os outros de Broken, podemos observar pontos de contato com o livro que foi "quebrado" para sua escritura. Unbroken, ao narrar a história de um submarino utilizado na Segunda Guerra Mundial, possui temas que aqui no poema também estão presentes: o mar, 
a morte e a escrita. A imagem do mar é constante neste livro, embora neste poema sua única aparição direta seja pelo vocábulo "espuma”; a morte, porém, pode ser associada ao mar e ser vista tanto nos tons escuros das imagens como nos versos nelas colados. No poema supracitado, parece haver um caminho que leva os "os estranhos/que somos// e os vivos que passam" a se transformarem em "anônimos// no retrato/ de um pálido Verão", é, logo, a inevitabilidade da morte e do apagamento da identidade dos que são por ela levados, dos quais só resta um retrato anônimo. Diante desse fato, a única esperança restante parece ser "o acaso// de um livro/ de espuma" que seria uma "voz corrente" entre esses homens fadados à finitude. Novamente, ocorre a mistura da atmosfera do poema e do livro-inspirador para a construçáo dele, assim como sua recorrente indeterminação: o "livro/ de espuma" seria Unbroken, Broken, ou outro? Poderemos pensar nos estranhos cujos rostos se tornariam anônimos como os personagens de Unbroken, incluindo seu próprio autor Alastair Mars? Ou a inspiração que esse livro faz aqui é somente emprestando suas palavras à tesoura? Perguntas que se mobilizam e, porém, não serão respondidas justamente por serem inúmeras as possibilidades de resposta. Esses questionamentos são a base de Broken, assim como nos outros títulos de Rui Pires Cabral, que se prestam à apropriação.

Mais livros semelhantes se seguiram a esses dois ainda no ano de 2013: Stardust, que contém um poema em uma página e uma colagem - sem palavras - em outra, sendo que há uma colagem diferente em cada um dos cinquenta e dois exemplares; e Álbum, formado por poemas compostos em cima de fotografias que se mantêm intactas, não recortadas. Por razóes de extensão, não nos deteremos nestes livros, deixando-os aqui apenas mencionados.

\section{A arte da apropriação}

Vimos, portanto, que a apropriação tem crescido ao longo dos últimos anos na literatura, sendo a poesia de Rui Pires Cabral somente um exemplo desta tendência. $\mathrm{O}$ poeta, que, desde suas primeiras publicaçóes incorporava trechos de cançóes e livros, trabalhando com a indeterminação e com o diálogo por tais inserçóes provocados, mais recentemente demonstrou, de maneira ainda mais visível, a citação como arte de recorte e colagem, como propôs Compagnon. Assim, antes o autor recortava os trechos que 
o interessava com os olhos e os transcrevia em suas páginas, mas, em seus últimos livros, fez uso da tesoura e da cola para enfatizar a apropriação que fez, tornando-a a "mais material possível" (CABRAL, 2012, p.5) - gesto que talvez busque justamente enfatizar como estas e outras obras fazem uso da palavra alheia para se fazerem.

\section{Referências}

CABRAL, Rui Pires. Música Antológica \& Onze Cidades. Lisboa: Presença, 1997. . Praças e Quintais. Lisboa: Averno, 2003. . Oráculos de Cabeceira. Lisboa: Averno, 2009a. . Biblioteca dos Rapazes. Lisboa: Pianola, 2012. . Broken. Lisboa: Paralelo W, 2013.

COMPAGNON, Antoine. O Trabalho da Citação. Belo Horizonte: Editora UFMG, 2007.

GREENBERG, Clement. Collage (1958).

GRENOUILLET, Corinne. Les Incipit: l'écriture et ses mythes chez Aragon (1998).

MAFFEI, Luis (Org.). Portugal, 0. Rio de Janeiro: Oficina Raquel, 2007. v. 2. MAGALHÃES, Joaquim Manuel. Rui Pires Cabral. In: Rima pobre. Lisboa: Presença, 1999.

PERLOFF, Marjorie. O gênio não original: poesia por outros meios no novo século. Belo Horizonte: Editora UFMG, 2013.

PIMENTA, Tamy de Macedo. Biblioteca dos Rapazes, de Rui Pires Cabral. Convergência Lusíada, n. 29, janeiro - junho de 2013. 


\title{
APPROPRIATION AND INDETERMINATION IN RUI PIRES CABRAL'S POETRY: FROM PERSONAL MEMORY TO THE 'MOST MATERIAL' INSPIRATION POSSIBLE
}

\begin{abstract}
This article intends to think about the techniques of appropriation that are used in the work of the contemporary Portuguese poet Rui Pires Cabral. The author inserts, since his first books, excerpts of music or literature in his poems, creating a dialog with other arts through writing. This dialog becomes even clearer with the recent use of collage by the poet, which is the 'most material inspiration possible.

KEYWORDS: Contemporary poetry; appropriation; collage.
\end{abstract}

Recebido em: 23/10/2014 Aprovado em: 10/12/2014 